\title{
ПЕДАГОГИЈА СТАРОЗАВЕТНЕ МУЗИКЕ
}

\author{
Нинослав Качарић* \\ Висока школа - Академија СПЦ за уметности и \\ консервацију, Београд
}

Сажетак: Молитва кроз песму је будила покајање и милост, изражавала радост, захвалност, похвалу, али и мољење, осећај кривиче, кајање, и све ове емочије су снажно подстицале субјективне изразе у песми. Старозаветна музичка молитвена педагогија је била основ и залог лепоте будућег хришћанског богослужења.

Кључне речи: музика, педагогија, Библија - Свето писмо Старог завета, Јевреји

\section{Увод}

„Јеврејска музика је она музика која је настала од Јевреја, за Јевреје и као Јевреји". ${ }^{1}$ Као и у осталим нацијама и етничким културама, музичка димензија јеврејске културе је одређена њеним пореклом и обликована историјским односима јединственим за јеврејски народ. Она је сачувана истим принципима и путем којим су ходили сви потомци древне блиско-источне високе културе. Музика је стварана, извођена и чувана усменом традицијом, која је подржана и у великој мери руковођена, вером и етичким учењем, кроз облике поезије и прозе сачуване писаном традицијом. Расељавањем по свету, Јевреји су дошли у контакт са мноштвом регионалних музичким стилова, обичаја и идеја, од којих су неки у ближој вези са њиховом постојбином и отаџбином, као што је на Блиском Истоку и широм Медитерана, а неки су суштински различити, као што је и у Европи. Сви ови фактори уобличују карактер тока развоја јеврејске музике, а такође одређују природу извора који би могли дати одређена сазнања и резултате.

\footnotetext{
*ел.пошта: ninoslav.kacaric@gmail.com

${ }^{1}$ Encyclopaedia Judaica, vol.12 (Jerusalem: Keter Publishing House, 1971), 555.
} 
Библија, а посебно Свето писмо Старог завета, је најистакнутији и најбогатији извор знања о музичком животу древног Израиља, до неког времена после повратка из вавилонског ропства. Њу допуњују и извештаје настављају археолошки остаци музичких инструмената и слике музичких догађаја, упоредни материјал из суседних култура и постбиблијски извори списи Филона Александријског, Јосифа Флавија, апокрифи и Мишна.

\section{Историјски развој}

Митска димензија музике је представљена у библијској традицији једино поменом Јувала, сина Ламеховог из рода Каиновог, од кога су се изродили гудачи и свирачи (Пост 4, 21). После великог потопа, музика се први пут помиње у причи о Лавановом разговору са Јаковом, навођењем инструмената бубњева и гусала, уз весеље и песму на испраћају (Пост 31 , 27). Сличан помен налази се у Књизи о Јову, где се сусреће најпре славље безбожничко уз бубањ, гусле и свиралу (Јов 21, 12), а касније и певање звезда јутарњих и клицање свих синова Божијих (Јов 38, 7).

У Другој Књизи Мојсијевој описан је догађај избављења Израиља из египатског ропства, чудо преласка преко Црвеног мора, погибија Египћана и, као круна свега тога, прослава Господа под вођством Мојсија и пророчице Марије уз бубњеве и свирале (Изл 15, 1-21). Према Глумцу „песма Деворе и Варака састављена је у изразитом метричком облику, и вероватно певана уз музичку пратњу као народна песма", а налази се у Књизи о Судијама 5, 1-31. Саула и Давида су, приликом њиховог повратка из победоносне битке против Филистејаца, поздравиле добродошлицом жене које су певале, свирале и играле (1Сам 18, 6-7). Музика је клицала и туговала, распаљивала и умиривала, она је водила до екстазе која је захватала пророке, и растеривала демоне из Саулове душе када је Давид, пастирски дечак, пред њим свирао. Професионални музичари се тада

${ }^{2}$ Душан Глумац, Библијска археологија (Београд: Богословски факултет у Београду - Србиње: Академија Св. Василија Острошког у Србињу, 1999), 164. 
још увек не спомињу, као ни систематско неговање музике, али је она била саставни део у пророчким школама.

Како наводи Курт Сахс „музички живот се изменио у време Давида и Соломона. Сасвим изненада се појављују страни инструменти управо као што су се појавили у Египту после 1500. године п.н.е: харфе, цитре, обое, цимбали, систруми. Фараонова ћерка коју је краљ Соломон узео за жену, по талмудском трактату Шабат, имала је наводно око хиљаду врста музичких инструмената у миразу (што не изгледа нарочито претерано с обзиром на тристодвадесетдевет жена музичара које је генерал Александра Великог заробио из пратње персијског краља Дарија)". ${ }^{3}$

Израиљ је почео у то време развијати музичаре по занимању, као и неку врсту музичке организације. Цар Давид је око себе окупио певаче и певачице (2Сам 19, 35), али и пре почетка његовог организовања певања, вероватно је било много музичара, јер је транспорт ковчега Завета праћен песмом и свирањем разноликих инструмената - бубњева, гусала, псалтира, свирала и кимвала (2Сам 6, 51; 1Дн 13, 8). Цар Давид је изабрао 4000 музичара од 38000 левита, или једног на десет у целом Левијевом племену, а од свих њих 288 је било посебно обучено (1Дн 25, 6-7). Пуни број је био подељен на 24 реда, сваки са 154 музичара над којима је било 12 специјално обучених вођа под једним од 24 синова Асафа, Имана и Једутина као диригентима, који су изгледа ударали у кимвале, вероватно да би означили време или можда ритам и тактове (1Дн 15, 19. 16, $5)$. Такође су и жене учествовале у храмовном певању (1Дн 13, 8 . $25,5-6)$, и ови хорови су одговарали једни другима антифонски.

Глумац наводи да је „на овај начин устројена, музика била торжествена и заносна, превазилазећи све пре тога времена". ${ }^{4}$ Цар Давид је био композитор песама и јадиковки, вешт свирач на лири (1Сам 16, 16-18), изумитељ инструмената (Ам 6, 5), цењени дворски музичар (1Сам 19, 9), па чак и играч (2Сам 6,

${ }^{3}$ Curt Sachs, The rise of the music in the ancient world east and west (New York: W. W. Norton \& Company, 1943), 60.

${ }^{4}$ Глумац, Библијска археологија, 165. 
14-15). Књижевни запис његових бројних способности може се упоредити са прослављањем изванредних талената у музици, атлетици и државништву сумерског краља Шулги од Ура (2093-2045. године п.н.е.), забележеним у бројним химнама које је сам написао.

Цар Соломон је такође био наклоњен организовању и неговању музике, прикупљањем певача, певачица и разних музичких справа (Проп 2, 8), као и стицањем угледа композитора многих песама - „тисућу и пет” (1Цар 4, 32). Када је и најзад могао да посвети храм, сви левитски певачи, односно Асаф, Иман и Једутин и њихови синови и другови по служби, обукли су се у фино платно, наместили се са цимбалима, харфама и лирама на источној страни олтара, а поред њих 120 свештеника који су дували у трубе. Онда су трубачи и певачи заједно пошли да као из једног гласа запевају песму хвале и славе Господа, и кад су своје гласове са трубама, цимбалима и жичаним инструментима подигли и Господа хвалили, дом - храм Господњи се испунио облаком тако да свештеници нису могли ући унутра да обаве своју службу, јер је величанство Господа испуњавало дом Божији (2Дн 5, 12-14).

У светилиштима изван Јерусалима музика је вероватно била много истакнутија, што видимо из постојања мноштва музичара уз пророке (1Сам 10, 5), као и из осуде пророка Амоса страних помпи у једном од култних центара северних племена - можда у Сихему (Ам 5, 23). После повратка из Вавилона, музика као света уметност била је по некима разлог за свађу између левитских певача и свештеника, и то може бити разлог за уметање или издвајање поеме „На водама Вавилонским” (Пс 137) у колекцији Псалама. Они који плачу у изгнанству нису били апстрактна персонификација - они су били левитски певачи којима би њихови освајачи придружили егзотичне дворске оркестре, које су асирски и вавилонски цареви чували за забаву и попуњавали их поробљеним музичарима. ${ }^{5}$

Дворски и храмовни оркестри Месопотамије су у овом периоду били прототип за храмовну музику у Јерусалиму по

${ }^{5}$ Encyclopaedia Judaica, vol.12, 560. 
повратку из ропства - велико тело жичаних инструмената (у Јерусалиму само кинор и невел), мали број или само пар цимбала и велики хор. У периоду после Другог Храма, о музици сведоче списи Филона Александријског, Јосифа Флавија, Кумранске заједнице Есена и Талмуд, показујући такође њен велики значај у богослужењу. Свакодневна храмовна музика је добро описана у талмудском трактату Тамид $(7,4)$, где је детаљно приказан ритуал јутарњег одласка свештеника у храм, жртвоприношење уз учешће првосвештеника, дување у две сребрне трубе (један дуго издржани тон, један трештав тон, и опет један дугоиздржани тон), и почетак левитске песме уз цимбал, а потом у паузама одјек труба и падање народа ничице. Левити су првог дана певали псалам 24, другог псалам 48, трећег псалам 82, четвртог псалам 94, петог псалам 81, шестог псалам 93, на шабат псалам 92, једну песму за дан и мир за вечни живот. По овом питању Сахс даје следећи опис: „Хор се састојао од најмање 12 певача старих између 30 и 50 година, који су, према једном не сувише јасном месту у талмудској гемари Хулин, проводили по свој прилици 5 година у вежбању. Дечаци левита су се могли прикључити хору да би допринели љупкости певања. У последње доба Храма, музички управник био је Хигрос бен Леви, који је имао велико име као сјајан виртуоз, али је успомена на њега запала у непоштовање јер своју уметност није хтео да пренесе ни на кога другог. Оркестар се у оно време састојао од 2 до 6 харфи, 9 или више лира, 2 до 12 обоа и једног пара цимбала. Први храм, који је био разорен у години 586. п.н.е. није располагао обоама у богослужењу". 6

Посебна врста музичке праксе и доктрине је развијена код секти тог времена, па је интересантно хорско певање секте Терапеута, које свој музички основ вероватно има у свицима са Мртвог мора. Изгледа да су они избегавали употребу музичких инструмената чувајући „плодове уста" - певање, као много чистији и интимнији израз побожности. Катастрофа разорења Јерусалимског храма 70 године п.н.е. запечатила је храмовно усредсређену музику јеврејског народа, и отворила

${ }^{6}$ Sachs, The rise of the music in the ancient world east and west, 62-63. 
нови период у којем је синагога постала централно место креативности речи и звука. Како наводи Џералд Абрахам „Јевреји су без сумње испољили своју уобичајену способност да очувају традицију и одупру се културној асимилацији, посебно у свему ономе што је везано за богослужење у Храму и њихову религију уопште, али је притисак хеленистичког света видљив посредно, управо кроз њихово одупирање. На пример, верска употреба инструмената, која је толико дуго била важан део обреда у Храму, након разарања Храма 70 године п.н.е. није била забрањена у знак жалости, као што се дуго веровало, већ је наилазила на противљење због тежње за очувањем чистоте верске музике пред музичким и оргијастичким мистеријама, у којима су сиријски и месопотамски Јевреји не тако ретко учествовали". ${ }^{7}$

Касна хеленистичка цивилизација је учинила музику свуда присутном културном активношћу. Источна сцена је била прошарана позориштима, аренама и циркусима, где су се певачи и инструментални виртуози сусретали и надметали. Звецкање, лупање и чегртање су били саставни део паганских култова. Укидање храмовног богослужења је такође учинило крај отменој инструменталној уметности Левита, па је употреба инструмената у синагогалној служби била забрањена, истичући само вредност вокалне уметности. Осим тога, музичка вештина левитских певача и њихова традиција, генерацијама преношена углавном усменим путем, није искоришћена у синагогалној песми, пошто њихово професионално учење и правила нису никада сачувани у писменом виду. Синагогална песма је стога била нови почетак у сваком погледу. У новој ери, молитва је требала заменити жртвоприношење, и подстаћи покајање и милост. За разлику од левитске музике, која је била саставни део жртвоприношења и није сматрана људским производом, него је имала основ и тежила је ка несхватљивој трансцедентној лепоти, синагогалном песмом су се појединац и заједница обраћали Богу кроз смисао отпеваних речи. Молитва - служба срца - је требала изразити многа људска осећања: радост,

${ }_{7}^{7}$ Jerald Abraham, Oxfordska Istorija Muzike, tom I (Beograd: Clio, 2001), 57. 
захвалност, похвалу, али такође и мољење, осећај кривице и кајање, и све ове емоције су снажно подстицале субјективне изразе у песми. Дар лепог гласа је обавезивао члана заједнице да прихвати функцију лаичког наставника и предводника (диригента) молитве. Основна карактеристика свих синагогалних стилова јесте мелодијска једноставност лако схватљива и извођена од целе заједнице.

\section{Музичке карактеристике}

Јеврејска музика пружа најбољи приступ вокалном стилу старог западног Оријента, јер је она, упркос извесним неизбежним променама, живела 4000 година без икаквог прекида. Стару традицију синагогалног певања нису прекинули многи векови живота јеврејског народа ван отаџбине. Абрахам Иделсон, сакупљач и истраживач јеврејских народних мелодија, доказао је у својим збиркама и радовима (Thesaurus of Hebrew Oriental Melodies) „да су обредни напеви најстаријих јеврејских заједница у Персији и Јемену идентични или бар веома слични мелодијама којима се у истим приликама (нпр. при рецитовању Старозаветних текстова) служе Јевреји у најновије време у Пољској, Немачкој и јужној Француској. Конзервативизам јеврејског предања сачувао је аутентични изворни карактер ових напева". ${ }^{8}$ Старо наслеђе је свакако најбоље сачувано у богослужењу оријенталних Јевреја, боље него код Сефарда у средоземљу или Ашкеназа у Европи, пошто они никада нису допустили да световна музика продре у синагогу, нити су допуштали својим канторима да импровизују. Не може се тачно утврдити каквим гласом су Јевреји певали и да ли је њихово певање заиста било викање у највишем гласовном регистру, као што указују описи из Псалма 22, где се појављује викање као начин обраћања Богу, па је „гласно певање нормални израз усрдне молитве и добро се слаже са наивном представом да ће Божија пажња лакше бити привучена жестином него уздржаношћу". ${ }^{9}$ Када је Самуилова мајка Ана ишла у Силом

\footnotetext{
${ }^{8}$ Muzička Enciklopedija, tom I (Zagreb: Leksografski zavod FNRJ, 1958), 749.

${ }^{9}$ Sachs, The rise of the music in the ancient world east and west, 85.
} 
да би се помолила за дете у Храму Господњем, покретале су јој се само усне, па је пророк Илија мислио да је пијана (1Сам $1,12-15)$. Тиха молитва до тада није била позната. Драстична антропоморфна представа да је Божије ухо најотвореније најгласнијем викачу, ипак је противуречила узвишеном Јудаизму пророка. Када су многобожачки пророци на Гори Кармилској призивали свога бога Вала, пророк Илија им се ругао и говорио: „Вичите већма јер је он бог! Ваљда се нешто замислио, или је у послу, или на путу, или може бити да спава, да се пробуди" (1Цар 18, 27).

Талмуд презире оне који читају Свето писмо без мелодије и проучавају речи без певања, и служба, која се ослањала на читање светих списа, била је у свим деловима музикална. Певање Псалама заузима важно место у јеврејском богослужењу и Хришћанским Литургијама. Спољашња и унутрашња организација овог певања блиско прати поетску форму. Сваки псалам се може састојати од већег или мањег броја стихова неорганизованих у симетричним строфама.

Према томе, мелодија једног стиха може постати музичка јединица која се понавља толико пута колико има стихова у псалму. Већина стихова је подељена у два једнака дела цензуром, па је и мелодији дата двострука структура. Библијски стих је састављен од бројних наглашених слогова па се стихови разликују у дужини, а укупан број слогова није константан. Мелодија се прилагођава овим променљивим варијантама, а то се изводи еластичношћу речитативног певања. Једноставан мелодијски материјал је лако схваћен и прихватан, па и репродукован од просечног члана заједнице већ после слушања стиха или два. Мелодија, после неколико понављања, губи своју занимљивост и није више примарна, него пажња аутоматски прелази на речи, које, у континуитету, стално нуде нешто ново, па „пратеће гласовне модулације спајају и формирају акустичну позадину која се инфилтрира у подсвест и креира посебно расположење које евентуално постаје асоцирано неким празницима или временом молитве, или тугом и другим емоцијама". ${ }^{10}$

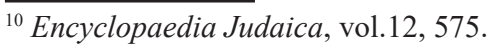


Мишна и Талмуд описују певање псалама, наводећи поделу између група певача. Предводник и група су се смењивали у певању пуном стихова или полустихова - предводник је могао интонирати (запевати) почетак, а хор (група певача) је преузимао или је можда певао завршне речи. Осим тога, стих, или део њега, могу послужити као рефрен, те је „антифонија музички пандан песничким паралелизмима. Овај израз значи, у ужем смислу, наизменично певање оба паралелна стиха од стране два полухора, а у ширем смислу, наизменично певање солисте са хором који одговара, што је у римској цркви названо респонзорнијалним певањем". ${ }^{11}$ Филон Александријски је објашњавао начин певања који сусрећемо у јеврејској традицији антифонијом. У својој Књизи о Мојсију, он пише: „На обали образоваше Хебреји од мушкараца и жена два хора и хваљаху Господа; Мојсије је отпочео песму мушкараца а његова сестра песму жена. Они су били предводници хорова". ${ }^{12}$ Када су жене, поводом Давидовог повратка после победе над Филистејцима, запевале и говориле у наизменичној песми: „Саул згуби своју тисућу, али Давид својих десет тисућа” $(1 \mathrm{Caм} 18,7)$, такође се пројавила антифонија. Када су вође после повратка из вавилонског ропства поново изградиле зидине Јерусалима, и када их је требало посветити, довели су Левите из свих њихових места да би посвећење било обављено уз радосну свечаност са захвалама и певањем, са цимбалима, харфама и лирама. Ту су се скупили и храмовни певачи, Немија је наредио да се старешине Јудеје попну горе на зидине, и поставио је две велике скупине певача који су хвалили Господа и ишли около - на десно половина вођа Јудеје и један део свештеника с трубама и музичким инструментима Давидовим, а други хор захвалника ишао је около и њима у сусрет остајући на тамничкој капији; и тако су оба хора захвалника стајала крај куће Господа и певачи су громко певали под Језрајом началником (Нем 12, 27-42). Старији рабини талмуда, који су се сећали Храма, описали су карактеристике овог певања, наглашавајући делове када су солиста и заједница наизменично певали, а та-

\footnotetext{
${ }^{11}$ Sachs, The rise of the music in the ancient world east and west, 99.

${ }^{12}$ Ibid., 100.
} 
кође су још у време Мојсија били прописани стални рефрени: „А сав народ одговарајући нека рече: амин” (Пнз 27, 15-26). Најбоље сведочанство за хорску антифонију даје Филонов опис вечерње службе секте Терапеута: „Заједно сви устају и два хора се образују, један од мушкараца а други од жена, и за сваки хор се бира по један предводник, који је најдостојнији и најбољи у скупини. Онда они певају химне које су у славу Бога компоноване у многим стиховним мерама и мелодијама, при чему једном сви певају заједно, а други пут један другом на спретан начин одговарају. Хор побожних мушкараца и жена производи у једноставном певању и у наизменичној игри мелодија заиста музикално сазвучје, при чему се продорни гласови жена мешају са дубоким гласовима мушкараца". ${ }^{13}$

У школама су деца понављала кантилацију учитеља после сваког полустиха, а основни метод обуке је била стара пракса хирономије (ручног закона) - знаци рукама и прстима који су указивали на средње, финалне и друге каденце библијског појања. Хирономија је била коришћена код певача древног Египта, а касније је такође усвојена у Византији. Пошто није било писаних акцената, овај начин је био код Јевреја у употреби све до периода масорета (друга половина првог миленијума), када су акценти постепено развијени и уведени у употребу, али „иако је каденцијална подела стихова и читачка мелодија дата на Гори Синајској, они су били изговорени у складу са усменом традицијом, а не са акцентним знацима у књизи". ${ }^{14}$ Природа овог једноставног, неписаног библијског појања, може бити изведена и у неколико наговештена садашњим обичајима неких заједница, посебно Јеменита, који још увек изостављају писане акценте и читају Библију у много једноставнијем маниру, користећи само добро познате каденце. Иако је немогуће доказати да су поједине мелодије данашње синагоге идентичне оним старим, могу се уочити принципи старог певања (нуcax), који су и данас присутни. Јеврејско молитвено певање јесте у основи еволуција традиционалних мелодијских оквира,

${ }^{13}$ Ibid., 101.

${ }^{14}$ Encyclopaedia Judaica, vol.12, 578. 
костура који се састоје од неколико мотива, без фиксног ритма и метра, способних да се прилагоде тексту. Мотиви могу бити понављани или изостављени, могу мењати места или подлећи променама од стране самог певача, а данас се налазе у заједницама Сефарда, Ашкеназа и сличним њима на Оријенту.

На списку имена неких инструмената има указања на новозаветно певање на богослужењу (Еф 5, 19; Кол 3, 16), међутим, нема ознаке ко је певао, или када се у току богослужења то догађало. Упућивања на певање небеских бића у Откровењу Јовановом $(4,10)$ и цитирани делови химни могу обезбедити увид у врсту музике коришћене у раном хришћанском богослужењу.

\section{Наслови псалама}

Око две трећине псалама одређује своје ауторство у насловима - или је то Давид - ,љупки псалмопевац Израиља” (2Сам $23,1)$, или су то, са само неколико изузетака, породице левитских музичара, доведена у везу са оригиналним оснивањем храмовног богослужења. Други термини и изрази у заглављима указују директније на музичке појмове, природу, сврху или начин извођења појединих композиција.

Неке песме се зову псалми због грчког превода (псалмос), јеврејског израза мизмор, а оба термина означавају песму уз инструменталну пратњу. Термин шир (реч условно изведена из акадског или сумерског језика) означава песму мољења, и заједничка је реч за молитву, а обично пре и после ње долази мизмор. Значење термина маскил и миктам су непознате, мада можда означавају „мудросни псалам” (маскил), и „псалам кајања" (миктам) у псалму 16, 56-60. Назив шигајон је сродан са акадском речју која означава врсту јадиковања и несрећног плача - тужбалица (Пс 7). Назив техила значи похвала (Пс $145)$, а тефила означава молитву (Пс 86; 90; 102; 142; 72).

Ови термини су означавали књижевну врсту псалама, а следећи указују на начине извођења.

Реч ламнацеах односи се на хоровођу, док термин бенегинот упућује на инструменте са жицама, а ел хан - нехилот на 
флауте (Пс 5). Термин ал аламот по Харингтону ${ }^{15}$ значи ,за сопрана" (Пс 46) тј. за девојке, а ал хаш - шеминит ,за дубоке гласове" (Пс 6 и 12), док се у Харперовом Библијском речнику $^{16}$ објашњава да ово може упућивати на врсту плеса, а можда и на ритам. Такође се у насловима налазе и шлагворти песама, ознаке или почетне речи познатих старијих песама на чије су мелодије псалми требали бити певани нпр. по напеву „Кошута у зору” (Пс 22), „Љиљани” (Пс 45)...

Често појављивање речи селах, која се налази у средини или на крајевима неких псалама, је вероватно такође нека врста ознаке извођења, и могла би значити паузу у певању, када је друга група певача или свирача могла наставити са певањем.

Ови подаци о Псалтиру се могу објаснити и мислима светих отаца: „Ако историја поучава, Закон Божији даје заповест за живот, пророчанства наговештавају будућност, поучне књиге уверавају и надзиђују, све то заједно чине Псалми Давидови (Амвросије Милански). Псалтир је врт у ком су сабрани сви плодови других књига и својим садржајем обухватају материју целокупне теологије (Св. Атанасије Велики)". ${ }^{17}$

\section{Музички инструменти}

Већина онога што знамо о инструментима Библије долази из књижевних сведочанстава - светих списа и њихових најранијих превода, описа и коментара рабина и црквених отаца. Додатни докази долазе од археолошких истраживања - остатака тадашњих инструмената и бројних сликаних представа инструмената и музичких догађаја - широм Блиског Истока и Медитеранског подручја. Ипак, „у употреби музичких инструмената било је много неизвесности код Јевреја, али су открића

\footnotetext{
${ }^{15}$ Wilfrid J. Harrington, Uvod u Stari Zavjet - Spomen obećanja (Zagreb:Kršćanska sadašnjost, 1977), 326.

${ }^{16}$ Sweeny Madeleine Miller \& John Lane Miller, Harper `s Bible dictionary (New York: Harper \& Row, 1973), 671.

17 Драган Милин, Кюижевно-музичке особине псалтира (Београд: Календар Српске Православне Патријаршије,1997).
} 
на египатским и асирским споменицима бацила више светла на облик и природу ових инструмената". ${ }^{18}$

\section{Дувачки инструменти}

1 .Шофар (арам, карна, керен ха-јовел): рог од овна или дивокозе, јесте најчешће помињани библијски инструмент, и једини древни инструмент који је још увек у употреби у синагоги. Реч је можда изведена из акадског назива за козорога или дивокозу, али је инструмент најчешће прављен од рога овна размекшаног на топлоти, исправљеног и обликованог. То је био једноставан инструмент који је могао произвести само два - три тона, и најчешће је коришћен за сигнализирање, посебно у временима рата (Нем 4, 18-20), или народних прослава (1Цар 1, 34; 2Цар 9, 13), а тек касније је добио мистичко значење. Свештеници су дували у њих на празник Сеница и када је почињала Јубиларна година. ${ }^{19}$

2. Хацоцра - труба направљена од драгоценог метала, углавном сребра или бронзе. То је био прав инструмент са високим, светлим звуком и опсегом од само четири или пет тонова. Њена рана употреба је лепо описана у Књизи Бројева (10, 2-10). Дували су у њих свештеници, најчешће у паровима, али повремено и у великим скупинама, по 120 на броју (2Дн 5, 1213), и то сваког новог месеца, изузев седмог, када је почињао празник Сеница. Убројане су у златне и сребрне сасуде Храма (2Цар 12, 14; Бр 31, 6).

3. Халил - флаута или фрула, јесте инструмент који је био састављен од две посебне цевке од трске, метала или слонове кости, сваке са својим писком. У фруле је свирано заједно, па је једна вероватно играла улогу зујеће пратње. То је примарно био световни инструмент, обично употребљаван у радосним приликама (1Цар 1, 39-40; Ис 5, 12), али је такође био погодан и за оплакивање (Jep 48, 36; Мт 9, 23).

4. Угав (сиринкс) - вероватно друга врста пастирске фруле, можда права флаута, мада га Септуагинта сматра жичаним ин-

${ }^{18}$ Глумац, Библијска археологија, 165.

${ }^{19}$ Милин, Кюижевно-музичке особине псалтира, 1997. 
струментом (органон, псалтир). Помињан је заједно са другим дувачким инструментима у Књизи Постања $(4,21)$ и Псалму $150,4$.

5. Дулцимер - гајде - врста инструмента са мехом и две пискаве цеви (Дан 3, 5).

6. Машрокита - пиштећи, звиждећи или цевасти, фруласти инструмент.

\section{Жичани инструменти}

1.Кинор - Давидова харфа је била стари семитски инструмент (Пост 4, 21; 31, 27), познат и у Египту, сличан грчкој китари или египатској лири. Овај инструмент је био популаран широм древног Блиског Истока, а реч се појављује у реченицама клинастог писма старе Сирије, као и у асирским, хуситским, хетитским, угаритским и египатским текстовима. То је био инструмент прослава пуних радости, који се обично употребљавао као пратња певању, а „својим обликом галилејско море подсећа на лиру. Назива се и Хинерот, што значи лира". ${ }^{20}$ Кинор је био састављен од тела, две ручке и јарма (причврсног ремена). Ханански тип инструмента, који је сигурно био исти са оним код Израелаца, јесте асиметричан, са једном ручком краћом него другом, и са телом у облику кутије. Инструмент је вероватно био просечне висине 20-23 инча (50-60цм) и звучао је у опсегу алта, као што показују сачувани примерци из Египта. Кинор је племенити жичани инструмент семитске цивилизације, и био је водећи у оркестру Другог Храма. Цар Давид је на њему свирао, па су га зато посебно поштовали Левити. По Јосифу Флавију, имао је 10 жица, прављених од малих овчијих црева.

2. Невел - инструмент сличан харфи, познат у целој Средњој Азији и Египту, са три или дванаест жица које су биле затегнуте усправно на отвореној страни оквира као што је често сликан на асирским рељефима у првом миленијуму. Можда је овим именом изначавана друга врста лире са звучном кутијом обликованом од поквашене коже, позната једино са представа

\footnotetext{
${ }^{20}$ Jacques Musset, Свет Библије (Београд: Хиландарски фонд при Богословском факултету, 2000), 68.
} 
на кованом новцу из времена Бар-Кохбе (132-135.г. п.н.е.), а назива се и лутом (Пс 150, 3). Дубљег је звука од кинора и свирана је окидањем прстију. Ванбиблијски извори, називајући га именом набла, помињу његов надахнути хучећи звук. То је био други по важности инструмент у храмовном оркестру. Према Мишни, његове жице су прављене од великих овчијих црева. Невел азор, или само азор (Пс $33,2.92,4.144,9)$ је вероватно био мало мањи невел са само десет жица.

3. Миним - вероватно жичани инструмент, можда лута, која никада није била саставни део хананског и израелског оркестра (Пс 150, 5. 45, 9).

4. Каитрос, сабекха и песантерин су арамејске ознаке за грчку китару, самбику и псалтерион.

\section{Ударачки инструменти}

1.Тоф - бубањ, којег је било више облика, а неки су подсећали на данашње. Египћани су имали дуги добош од дрвета или бакра који је потсећао на индијански там-там, и ударан је рукама. Други бубањ је био од бакра, већи по обиму, а ударан је палицама, док је трећа варијанта била варијанта више као наш добош са таламбас прапорцима који је, по тврдњи рабина, био у храмовном дворишту да позива свештенике на молитву, а могао се чути од Јерусалима до Јерихона.

2. Тимбрел (тамбурин) - уски обруч пресвучен кожом и ударан руком. На Египатским споменицима постоје три врсте: кружан, четвртаст и један сачињен од два четвртаста дела, повезана полугом и пресвучена кожом.

3. Шалишим - троугао, даире - женски инструмент коришћен за пратњу игара (Пс 150, 3; 1Сам 18, 6-7). То је био метални рам по некад са ручком и малим звоницима около. Држан је у руци и на њему су жене свирале на свадби и весељу.

4. Менааним (2Сам 6, 5) - инструмент на којем се свирало уз друге, приликом Давидовог преноса Ковчега у Јерусалим. Паралелна прича у 1Дн 13, 8. користи термин мезилтаим, а вероватно је сродан назив и зилзалим што означава цимбала. Цимбала пронађена у ископинама направљена су од бронзе, у облику плоча са централним удубљењем и металном омчом 
што долази око палца и кажипрста, а пречник је био око 12цм. Свирали су их Левити у храму, а налик су на кастањете и чинеле. Свирали су их Левити у храму, а налик су на кастањете и чинеле. Сродан термин је мезилот, споменут код Захарије $(14,20)$, и вероватно означава металне звечке које се могу видети на сирским рељефима. Такође су постојале бројне глинене звечке које су касније замењене металним звонима, а такође и систруми.

5. Паамон, римон - прапорци, звонца - помињу се само у Књизи Изласка 28, 33-34; и 39, 26, 26, и касније код Јосифа Флавија, као причвршћени на одежду првосвештеника, вероватно од злата направљени. Бољи превод је металне значке плочице, пошто права звона са клатном нису била позната у Израелу до 9.в. п.н.е, а ушла су у употребу у 7.в. п.н.е. Била су направљена од бронзе, са гвозденим клатном.

Код пророка Данила у трећој глави, налази се листа инструмената који су наводно коришћени на двору Вавилонског цара Навуходоносора (604-562г. п.н.е.). То су арамејски изрази или арамејски облици грчких речи, за које се не може са сигурношћу рећи шта означавају. Они се вероватно односе на криви рог, флауту, фрулу или панову фрулу, малу харфу, лиру или рани облик цитре. Израз симфонија значи ,звучање заједно”, и врло је вероватно да се термин не односи на један инструмент, него значи заједнички звук свих поменутих инструмената. У Псалму 150. су поменути скоро сви инструменти: „Хвалите Га уз глас трубни, хвалите Га уз псалтир и гусле, хвалите Га с' бубњем и весељем, хвалите Га уз жице и орган, хвалите Га уз јасне кимвале, хвалите Га уз кимвале громовне. Све што дише нека хвали Господа. Алилуја" (Пс 150). Према Харперовом Библијском речнику „у Новом завету су поменута четири инструмента: дупла фрула (двојнице), лира (харфа), труба и цимбала". ${ }^{21}$

\section{Фолклор и вера}

Мелодијско читање библијских текстова и молитвено појање је оригинално настало из народне ризнице облика про-

${ }^{21}$ Miller \& Miller, Harper `s Bible dictionary, 671. 
жетих религијским идејама. Извештаји о народном уживању у музици су ретки у раној библијској историји. Музика је увек била део прослава, било да је опроштајна забава употпуњавана весељем и песмама, тамбурином и лиром (Пост 31, 27), било да су слављени повратци кући (Суд 11,34), или да су празници пуни одмора провођени уз лиру и харфу, тимбрел и флауту и вино (Ис. 5, 12). Радници су обично певали олакшавајући себи монотони тешки рад (берба грожђа - Jep 25, 30; 48, 33), а жене су певале при напорном окретању жрвња, и сваким поводом је израиљска земља музике и певања.

Вођење ратова је подстицало појаву ратничких борбених песама. Такве херојске баладе су вероватно биле записане у изгубљеној „Књизи ратова Господњих” (Бр 21, 14), и Књизи Исуса Навина (ИНав 10, 13; 2 Сам 1, 18), а певали су их путујући свирачи (песници) и барди (Бр 21, 17-18). Марија је певала о Мојсијевом последњем поразу фараона (Изл 15, 20-21). Девора је певала песму тријумфа над Јавином (Суд 5), а Самсон је ликовао због убијања филистејаца $($ Суд 15,16$)$ ритмичном победном песмом налик оној коју су певале жене приликом Сауловог повратка кући (1Сам 18, 6-7). Израиљ није увек био победнички, па су песме компоноване и за пале хероје, као што је Давидова дирљива јадиковка за Саулом и Јонатаном (2Сам 1, 19-27). Јадиковање уцвељених жена над умрлим могло је преузети облик погребне песме (жалопојке), али је најчешће остајало кратко узвикивање, вероватно понављаних актуелних мелодијских фраза. Духовне вође вавилонских Јевpeја су се противиле народном извођењу музике као неприкладном за нацију у жалости, а њихов негативни став је још више утврђен када је феудална аристократија учинила музику делом њиховог хедонистичког уживања у животу. Никада, међутим, није постојала икаква забрана извођења музике на свечаностима венчања - баш напротив - ту је музика сматрана религиозном службом. Свирање флауте било је присутно како у брачној свечаности (симболисало је плодност), тако и на сахранама (симболисало је вечни живот и васкрсење), и било је уобичајено у време Јосифа Флавија и Јеванђеља. 


\section{Закључак}

Као код свих оријенталних народа, јеврејска музика је била више мелодична него хармонична, и имала је изразито педагошки карактер. Сви, старо и младо, мушко и женско, певачи и свирачи, изгледа да су један део певали унисоно или у октавама, али су саме мелодије на жалост изгубљене. Иако компаративне студије о животу Јевреја и других блискоисточних народа могу указати на неке друге мелодијске форме и елементе као веома старе, њихово приписивање библијском или раном пост-библијском периоду не може бити потврђено неким објективним доказима. Лепота музике састојала се у мелодији, али је она са толико много инструмената и гласова била тако љупка да је цео антички свет био пун похвала овој музици. Уз њу су битке задобијане, градови освајани, побуне угушиване, болести лечене, али изнад свега, узносиле су се молитве ка Господу, и у том смислу је њена молитвена педагогија била основ и залог лепоте будућег хришћанског богослужења.

\section{Литература:}

Anreis, Josip. Historija Muzike, prva sveska. Zagreb: Školska knjiga, 1966.

Библија - Свето Писмо Старог и Новог Завета. Београд: Библијско друштво СЦГ, 2004.

Blom, Eric. Grove 's dictionary of music and musicians. London: McMillan Publishers Ltd, 1954.

Глумац, Душан. Библијска археологија. Београд: Богословски факултет у Београду - Србиње: Академија Св. Василија Острошког у Србињу, 1999.

Деспић, Дејан. Мали речник музичких инструмената. Београд: Савез друштава музичких и балетских педагога Србије, 1992.

Encyclopaedia Judaica. Volume 12. Jerusalem: Ketler Publishing House, 1971.

Jerald, Abraham. Oxfordska Istorija Muzike. Tom I. Beograd: Clio, 2001.

Miller, Sweeny, M. \& Miller, John L. Harper`s Bible dictionary. 
New York: Harper \& Row, 1973.

Милин, Драган. Кюижевно-музичке особине псалтира. Београд: Календар Српске Православне Патријаршије, 1997.

Musset, Jacques. Cвет Библије. Београд: Хиландарски фонд при Богословском факултету, 2000.

Muzička enciklopedija. Tom I. Zagreb: Leksografski zavod FNRJ, 1958.

Радовановић, Тихомир. Лекиије из Светог писма Старог завета. Београд: Удружење студената Православног Богословског факултета Београдског Универзитета, 1930.

Harrington, Wilfrid, J. Uvod u Stari Zavjet - Spomen obećanja. Zagreb: Kršćanska sadašnjost, 1977.

Sachs, Curt. The history of music instruments. New York: W. W. Norton \& Company, 1940.

Sachs, Curt. The rise of the music in the ancient world east and west. New York: W. W. Norton \& Company, 1943.

Sendrey, Alfred. Musik in Alt-Israel. Leipzig: Deutscher Verlag für Musik, 1970. 


\title{
PEDAGOGY OF THE BIBLE`S OLD TESTAMENT MUSIC
}

\author{
Ninoslav Kačarić \\ Academy of Serbian Orthodox Church for Fine Arts and \\ Conservation, Belgrade \\ e-mail: ninoslav.kacaric@gmail.com
}

Summary: Old Testament prayer - the service of the heart - was supposed to replace sacrifice, to encourage repentance and mercy, to express many human feelings: joy, gratitude, praise, but also prayer, guilt and remorse, and all these emotions strongly encouraged subjective expressions in the song. The music was created, performed and kept by oral tradition, which was supported and largely guided by faith and ethical teaching, through various forms of poetry and prose preserved by written tradition. Music had a pedagogical significance and was always a part of the celebrations, whether the farewell party was complemented by joy and songs, tambourine and lyre, whether the return home was celebrated, or that the holidays were full of rest with lyre and harp, timbrel, flute and wine. Workers usually sang to ease their monotonous hard work, women sang while working hard, while waging wars encouraged the appearance of warrior songs. On every occasion, the land of Israel was permeated with music and song. Her prayer pedagogy was the basis and pledge of the beauty of future Christian worship. Jews

Keywords: music, pedagogy, the Bible - the Bible's Old Testament, 